ELEOS: Jurnal Teologi dan Pendidikan Agama Kristen

Sekolah Tinggi Teologi Kalvari Manado

ISSN 2798-9771 (Online), 2798-9860 (Print)

Volume. 1, Nomor. 2, Edisi Januari 2022 (Hal. 75-87)

DOI: 10.53814/eleos.v1i2.10

https://sttkalvari.ac.id/ojs/index.php/eleos/index

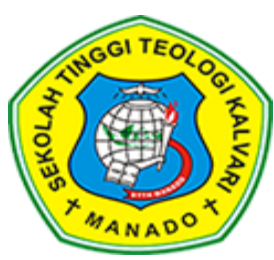

\title{
Peran Guru Profesional dalam memajukan Pendidikan di Era Industri 4.0
}

\author{
${ }^{1}$ Wadison Petrus, ${ }^{2}$ Dewi Suri Agustina Nainggolan, ${ }^{3}$ Talizaro Tafonao \\ 1,2,3,4 Sekolah Tinggi Teologi REAL Batam \\ ${ }^{1}$ wadisonpetrus15@gmail.com, ${ }^{2}$ dewisurinainggolan1708@gmail.com, \\ ${ }^{3}$ talizarotaf@sttrealbatam.ac.id
}

\begin{abstract}
The purpose of writing this article is to see what obstacles are faced by teachers in improving educational progress in the industrial era 4.0. This research is based on the community's point of view that education is the main aspect in bringing about change for the progress of the nation. This can be seen from the appreciation of the community in encouraging their children to go to school, because through education they can be freed from the shackles of ignorance and backwardness. However, this expectation has not been achieved due to the many obstacles faced by teachers in improving their professionalism in teaching as explained in this article. This paper uses a qualitative method by examining the professional role of teachers in advancing education in the industrial era 4.0. The author collects data through the study of journal articles, books and scientific works that can be trusted to support the author's analysts in writing this article. The results obtained in this study are teachers understand the meaning of professionalism in the world of education, problems in the world of education, rights and obligations in educational change, the function of the teacher's role in supporting educational progress in the industrial era 4.0. Thus, improving education in the industrial era 4.0 is the responsibility of every teacher.
\end{abstract}

Keywords: Role, Teachers, Professionals, Education, Students, Industry 4.0, Technology

\begin{abstract}
Abstrak: Tujuan penulisan artikel ini adalah melihat apa saja kendala yang dihadapi oleh guru dalam meningkatkan kemajuan pendidikan di era industri 4.0. Penelitian ini didasarkan dari pandang masyarakat bahwa pendidikan merupakan aspek utama dalam membawa perubahan bagi kemajuan bangsa. Hal ini terlihat dari apresiasi masyarakat dalam mendorong anakanaknya untuk bersekolah, karena melalui pendidikan dapat dimerdekakan dari belenggu kebodohan dan keterbelakangan. Namun harapan ini masih belum tercapai disebabkan karena banyak kendala yang hadapi oleh guru dalam meningkatkan profesionalnya dalam mengajar sebagaimana penjelasan dalam artikel ini. Tulisan ini mengunakan metode kualitatif dengan
\end{abstract}


W. Petrus, D. S. A. Nainggolan, T. Tafonao: Peran Guru Profesional dalam memajukan...

mengkaji peran profesional guru dalam memajukan pendidikan di era industri 4.0. Penulis mengumpulkan data melalui kajian artikel jurnal, buku dan karya ilmiah yang dapat dipercaya untuk mendukung analis penulis dalam penulisan artikel ini. Hasil yang diperoleh dalam kajian ini adalah guru memahami makna profesional dalam dunia pendidikan, masalah dalam dunia pendidikan, Hak dan Kewajiban dalam perubahan pendidikan, fungsi peran guru dalam mendukung kemajuan pendidikan di era industri 4.0. Dengan demikian bahwa peningkatan pendidikan di era industri 4.0 merupakan tanggung jawab setiap guru.

Kata Kunci: Peran, Guru, Profesional, Pendidikan, Siswa, Industri 4.0, Teknologi

\section{Pendahuluan}

Kajian ini akan menjelasakan kinerja guru dalam menghadapi pendidikan era industri 4.0. Pada era industri 4.0 ini, teknologi informasi menjadi basis atau dasar dalam kehidupan manusia termasuk bidang pendidikan. Salah satu ciri pendidikan di era industri 4.0 adalah memanfaatan teknologi sebagai sarana dalam proses belajar mengajar (cyber system), sehingga pelaksanaan pembelajaran tidak harus duduk di dalam kelas atau bertatap muka seperti yang terjadi di masa pandemi ini, semua aktifitas pembelajaran dilakukan secara daring. Dalam kajian yang dilakukan oleh Wibawa dan Pritandhari mengatakan pada di era digital ini, teknologi memegang peranan penting dalam proses pembelajaran di era revolusi industri $4.0{ }^{1}$

Berdasarkan penjelasan tersebut di atas, penulis memperhatikan bahwa dengan memanfaatkan teknologi dalam proses pembelajaran saat ini, maka semua materi ajar dapat sampai ke peserta didik setiap saat tanpa batas ruang dan waktu, tetapi perlu diperhatikan bahwa dalam pelaksanaan ini harus menyiapkan perangkat teknologi digital yang cukup memadai, kurikulum yang sesuai dengan perkembangan zaman serta tenaga pendidik yang mempunyai kecakapan dalam memanfaatkan Information and Tehnology pembelajaran. Dengan kata lain bahwa di era industri 4.0 ini sangat membutuhkan guru yang profesional yang tidak tergantikan dengan kecanggihan teknologi.

Pernyataan di atas merupakan hal yang menarik untuk dibahas dalam tulisan ini guna menyadarkan para pendidik bahwa peran guru sebagai profesi merupakan pilar penting bagi kemajuan bangsa dan seharusnya peran ini diharapkan tidak dianggap sebelah mata. Sekalipun bangsa Indonesia ini memiliki Sumber Daya Alam yang melimpah (SDA), namun hal ini tidak dapat menjadi jawaban, jika tidak memiliki Sumber Daya Manusia (SDM) yang mumpuni dalam bidangnya khususnya dalam penguasaan teknologi. Dua aspek ini tidak boleh diabaikan, oleh karena itu perlu adanya peningkatan secara profesional kepada seorang pendidik karena hal ini merupakan yang urgen dalam menyelesaikan berbagai problem yang ada.

${ }^{1}$ Fajri Arif Wibawa and Meyta Pritandhari, "Pemanfaatan Teknologi Informasi Dalam Pembelajaran Era Revolusi Industri 4.0," in Seminar Nasional Penelitian Dan Pengabdian Kepada Masyaraka, vol. 3 (Lampung: Universitas Muhammadiyah Metro, 2020), 109-117. 
W. Petrus, D. S. A. Nainggolan, T. Tafonao: Peran Guru Profesional dalam memajukan...

Kata profesi merupakan suatu pekerjaan yang dilakukan oleh seseorang sebagai aktifitas utama dalam menghidupkan dirinya sendiri. Sedangkan kata profesional adalah suatu pekerjaan yang menuntut pada suatu keahlian, tanggung jawab dan kesetiaan pada suatu pekerjaan yang sedang dikerjakan oleh seseorang. ${ }^{2}$ Hal ini juga guru disebutkan sebagai guru profesional sebagaimana yang telah diatur dalam Undang-Undang Nomor 14 Tahun 2005 ayat 1 bahwa guru adalah pendidik profesional dengan tugas utama mendidik, menilai, dan mengevaluasi peserta didik pada pendidik anak usia dini jalur pendidikan formal, pendidikan dasar, dan pendidikan menengah. ${ }^{3}$ Artinya guru sebagai pilar yang diharapkan dalam kemajuan bangsa melalui pendidikan dan apa lagi Indonesia ini sebagai Negara yang berkembang tentu sangat memerlukan peran guru dalam memerdekakan generasi bangsa menjadi generasi yang bebas dari kemiskinan ilmu dan finansial. Oleh karena itu diperlukan Sumber daya Manusia yang unggul untuk memajukan bangsa ini. Dengan adanya Sumber Daya Manusia unggul maka persolan-persoalan yang ada dapat diselesaikan dengan baik. ${ }^{4}$

Istilah kata "guru" berasal dari bahasa inggris yaitu teacher, yang artinya pengajar. Namun, dalam realitanya untuk sebutan sehari-hari, masyarakat Indonesia tidak memakai istilah pengajar sebagai panggilan kepada pendidik, tetapi lebih senang memanggil dengan sebutan guru, sebab dengan memakai istilah guru, maka masyarakat mengharapkan sosok guru tersebut dapat menjalankan tugas dan fungsinya dengan baik di dalam masyarakat. Ada dua tugas yang dimiliki oleh guru, yakni mendidik dan mengajar. ${ }^{5}$ Jika dikaitkan dengan pembahasan sebelumnya, maka peran guru sebagai profesi tidak dapat tergantikan oleh teknologi. ${ }^{6}$ Artinya peran guru sebagai profesi berbeda dengan peran profesi lainnya, yang pada suatu saat akan digantikan dengan teknologi/robot. Sebab, guru dalam keberadaanya merupakan sutradara di sekolah yang digugu dan ditiru. Menurut hemat Tafonao bahwa arti digugu dan tiru adalah guru langsung memberi contoh tentang hal-hal positif kepada setiap anak berkaitan dengan karakter yang baik. ${ }^{7}$ Namun, penjelasan ini bukan berarti guru tidak belajar menggunakan teknologi. Sebab di era industri 4.0 ini guru justru dituntut untuk mampu menguasai dan mempergunakan teknologi sebagai sarana utama dalam menjalankan proses pembelajaran. Menurut hemat A Kau

2 Amir Sahaka, "Profesi, Profesional Dan Pekerjaan," Jurnal Teknologi Pendidikan Madrasah 2, no. 1 (2019): 61-69.

${ }^{3}$ Fitri Mulyani, "Konsep Kompetensi Guru Dalam Undang-Undang Nomor 14 Tahun 2005 Tentang Guru Dan Dosen (Kajian Ilmu Pendidikan Islam)," Jurna Pendidikan Universitas Garut 3, no. 1 (2015): 1-8.

${ }^{4}$ Hastarini Dwi Atmanti, "Investasi Sumber Daya Manusia Melalui Pendidikan," Dinamika Pembangunan 2, no. 1 (2005): 30-39.

5 M. Hasyim M. Hasyim, "Penerapan Fungsi Guru Dalam Proses Pembelajaran," AULADUNA: Jurnal Pendidikan Dasar Islam 1, no. 2 (2014): 265-276.

${ }^{6}$ Susilo Setyo Utomo, "Guru Di Era Revolusi Industri 4.0," Format Pendidikan Untuk Meningkatkan Daya Saing Bangsa 1, no. 1 (2019): 70-83.

7 Talizaro Tafona'o, “Kepribadian Guru Kristen Dalam Perspektif 1 Timotius 4:11-16," Evangelikal: Jurnal Teologi Injili dan Pembinaan Warga Jemaat 3, no. 1 (2019): 62-81. 
W. Petrus, D. S. A. Nainggolan, T. Tafonao: Peran Guru Profesional dalam memajukan...

bahwa terjadinya pengoptimalan dalam proses pembelajaran yang dilakukan oleh guru itu karena pengaruh dari peran dan fungsi seorang pendidik di kelas. ${ }^{8}$

Berdasarkan penjelasan tersebut di atas, maka yang menjadi rumusan dalam tulisan ini adalah apakah peran profesional guru dapat meningkatkan kemajuan pendidikan di era industri 4.0. Dengan rumusan tersebut, maka yang menjadi tujuan artikel ini adalah melihat apa saja kendala yang dihadapi oleh guru dalam meningkatkan kemajuan pendidikan di era industri 4.0.

\section{Metode Penelitian}

Kajian ini menggunakan metode kualitatif. Penelitian kualitatif Menurut Junaidi adalah mencari makna di balik suatu kejadian, fenomena, dan gejala sosial yang dapat dijadikan sebagai pembelajaran berharga bagi pengembangan konsep teori. ${ }^{9}$ Tulisan ini memperoleh data melalui kajian pustaka dan menelusuri berbagai karya ilmiah yang sudah dipublikasikan berkaitan dengan kajian ini. Penulis mengumpulkan data melalui kajian terhadap artikel jurnal, buku dan karya ilmiah yang dapat dipercaya. Kemudian penulis menganalisis data dan mendeskripsikan melalui teknik analisis data dengan beberapa tahap, yakni mereduksi data, mengklasifikasikan dan memverifikasi data berkaitan dengan kajian terhadap artikel ini.

\section{Hasil dan Pembahasan.}

\section{Memahami makna guru sebagai profesi dalam dunia pendidikan}

Sebagaimana telah dipaparkan sebelumya bahwa guru memiliki peran dan tanggung jawab dalam mencerdaskan anak bangsa melalui kegiatan mengajar dan mendidik. Artinya guru memiliki makna penting dalam dunia pendidikan. Dimana makna ini dapat dilakukan dengan tidak melihat batasan wilayah atau pun tempat. Sebab dimana saja guru dapat memberikan pengajaran, dalam artian guru sebagai lentera kegelapan dalam akal tidak harus melaksanakan tugasnya di sekolah semata melainkan dimana saja hendaknya guru tetap memberikan pengajaran. Sehubungan dengan ruang wilayah yang tidak terbatas ini Ludo Buan menjelaskan bahwa siapa saja dapat memberi pengajaran asalkan memiliki kemampuan dalam mengedukasi setiap masyarakat (anak didik) tanpa memandang status laki-laki atau perempuan. Artinya baik wanita dan pria dijadikan sebagai guru bila ia bertanggung jawab memberikan pengajaran atau bantuan kepada anak didik dalam perkembangan jasmani dan rohani agar mencapai kedewasan. ${ }^{10}$

Selain itu, guru memiliki tanggung jawab dan wewenang mutlak dalam menentukan tujuan pembelajaran. Namun dalam tanggung jawab ini menuntut guru untuk tetap

8 Murhima A Kau, "Peran Guru Dalam Mengembangkan Kreativitas Anak Sekolah Dasar," in PROCEEDING SEMINAR DAN LOKAKARYA NASIONAL BIMBINGAN DAN KONSELING 2017, vol. 1, 2017, $157-166$.

${ }^{9}$ M. Djunaidi Ghony and Fauzan Almanshur, Metodologi Penelitian Kualitatif, ed. Ar-Ruzz Media (Yogyakarta, 2012).

${ }^{10}$ Yohana Afliani Ludo Buan, Guru Dan Pendidikan Karakter: Sinergitas Peran Guru Dalam Menanamkan Nilai-Nilai Pendidikan Karakter Di Era Milenial, Ed. Oleh Lorensius Amon (Indramayu: Adab, 2021). 
W. Petrus, D. S. A. Nainggolan, T. Tafonao: Peran Guru Profesional dalam memajukan...

mengupgrade dirinya demi meningkatkan kualitas profesionalnya dalam mempertahankan mutu pendidikan sebagai bukti pengabdiannya. Sebab hal ini suatu kemustahilan bila mutu pendidikan didapatkan dari guru yang tidak memiliki kualitas yang memadai, baik secara keterampilan maupun akademik. Oleh karena itu setiap guru dituntut memahami profesinya sebagai pendidik.

Istilah profesi berasal dari bahasa inggris, yaitu profession yang artinya "mampu atau ahli dibidang tertentu. ${ }^{11}$ Artinya seseorang dikatakan ahli jika ia telah dipersiapkan dalam suatu pendidikan yang khusus dan matang dalam kurun waktu yang lama. Selain itu, menurut hemat Kesuma Putri dan Imaniyati menegaskan bahwa peningkatan profesi para guru merupakan suatu proeses untuk menuju kepada profesional baik secara pendidikan maupun secara pengajaran. ${ }^{12}$

Berdasarkan penjelasan tersebut dapat memberikan pemahaman bahwa guru sebagai profesi. Profesi pada dasarnya merupakan sebuah jabatan yang harus diaktulisasikan dalam setiap kinerjanya. Hal ini juga yang diungkapkan oleh Warnsono dalam penelitianya bahwa profesi merupakan suatu aktifitas utama dalam menghasilkan nafkah hidup dengan didukung suatu keahlian. ${ }^{13}$ Dengan memaknai guru sebagai profesi di dunia pendidikan menuntut guru untuk memiliki keahlian demi mewujudkan tujuan pendidikan nasional. Tentunya keahlian ini didasari dari latar belakang pendidikan guru, sertifikasi guru dan juga kompetensi guru. ${ }^{14}$ Ketiga hal ini yang diharapkan menjadi persyaratan utama dalam menentukan kelayakan sebagai profesioanal.

\section{Guru memahami berbagai masalah dalam dunia pendidikan}

Salah satu masalah yang selalu dibicarakan dalam dunia pendidikan yaitu Sumber Daya Manusia. Pembenahan Sumber Daya Manusia merupakan cita-cita pemerintah dalam meningkatkan kualitas pendidikan di Indonesia. Sekalipun hal ini masih belum. Hal ini menjadi evalusi bersama untuk menjadi tanggung jawab bersama serta dapat diperhatikan, karena Indonesia tidak akan bisa maju jika ada dukungan dari berbagai elemen. Itu sebab pemerintah saat ini mengejar ketertinggalan tersebut untuk melahirkan Sumber Daya Manusia yang kompetitif.

Perwujudan ini dapat terealisasi melalui pendidikan. Pendidikan bukanlah segalanya, namun perlu diketahui bahwa segala sesuatu berawal dari pendidikan. ${ }^{15}$ Dengan ungkapan seperti ini dapat memberi pengertian kepada semua orang bahwa pendidikan merupakah hal

${ }^{11}$ Syarifuddin Abdullah, "Zakat Profesi," Jakarta: PT. Moyo Segoro Agung (2003).

${ }^{12}$ Ayu Dwi Kesuma Putri and Nani Imaniyati, "Pengembangan Profesi Guru Dalam Meningkatkan Kinerja Guru (Professional Development of Teachers in Improving the Performance of Teacher)," Jurnal Pendidikan Manajemen Perkantoran 2, no. 2 (2017): 202-211.

${ }^{13}$ Warsono Warsono, "Guru: Antara Pendidik, Profesi, Dan Aktor Sosial," The Journal of Society \& Media 1, no. 1 (2017): 1-10.

${ }^{14}$ Qomario Qomario, Siti Kurniasih, and Hetty Anggraini, "Studi Analisis Latar Belakang Pendidikan, Sertifikasi Guru Dan Usia Guru Paud Di Kota Bandar Lampung Berdasarkan Hasil Nilai Uji Kompetensi Guru (UKG)," Jurnal Caksana: Pendidikan Anak Usia Dini 1, no. 02 (2018).

${ }^{15}$ I Wayan Cong Sujana, "Fungsi Dan Tujuan Pendidikan Indonesia," Adi Widya: Jurnal Pendidikan Dasar 4, no. 1 (2019): 29-39. 
W. Petrus, D. S. A. Nainggolan, T. Tafonao: Peran Guru Profesional dalam memajukan...

penting dalam kehidupan manusia. Berdasarkan UU Sisdiknas No.20 tahun 2003, bahwa pendidikan adalah usaha sadar dan terencana untuk mewujudkan suasana belajar dan proses pembelajaran agar peserta didik secara aktif mengembangkan potensi dirinya untuk memiliki kekuatan spiritual keagamaan, pengendalaian diri, kepribadian, kecerdasan, akhlak mulia, serta keterampilan yang diperlukan dirinya dan masyarakat. ${ }^{16}$

Penjelasan ini tidak terlepas pada kualitas seorang guru yang profesional menghasilkan anak didik yang berkualitas. Tetapi berbeda apa yang terjadi saat ini dimana kualitas pendidikan di Indonesia masih jauh dari harapan tidak seperti negera-negara yang sudah maju. Ada tiga masalah yang dihadapi oleh Indonesia dalam dunia pendidikan, yaitu (1) kurangnya guru yang berkualitas. Hal ini berkaitan mengenai standar akan persayaratan guru yang masih longgar. Masih ada guru-guru yang belum memenuhi standar. Bahkan ironisnya, banyak guru yang tidak memiliki gelar kependidikan akan keahlian bidang pengajaran. (2) kurikulum. Dengan memperhatikan kurikulum yang selalu berganti, tidak jarang memberikan kesulitan kepada guru sebagai tenaga kependidikan dalam menjalankan tugasnya. Memang pembaharuan kurikulum pada dasarnya merupakan upaya untuk meningkatkan kualitas pendidikan dengan segala dimensi. (3) peserta didik. Ini adalah masalah yang serius. Sebab korelasi antara pelaksanaan kualitas kependidikan dan kurikulum diterima dan diajarkan kepada peserta didik. Peserta didik adalah kumpulan beberapa anak dengan keberagaman yang menonjol. Dimana keberagaman ini tentunya menempatkan keunikan sebagai hal yang patut disyukuri. Dalam kesimpulan penelitian yang dilakukan oleh Keriapy mengatakan bahwa keberagaman di sekolah merupakan sarana dalam melaksanakan proes pengajaran, sehingga siswa dapat belajar menghargai satu dengan yang lain. ${ }^{17}$ Pada hakekatnya keberagaman ini meliputi keberagaman pemikiran, keberagaman latar belakang, keberagaman potensi anak yang kerap kali dijadikan satu oleh tenaga kependidikan, dengan kata lain guru memaksakan apa yang dikehendakinnya agar dilakukan oleh siswa. Pemaksaan akan pembelajaran yang dikonsepkan oleh guru untuk dicapai oleh siswa menjadi problem akan masalah pendidikan. ${ }^{18}$

Berkaitan dengan penjelasan masalah di atas, penulis beranggapan bahwa perlu adanya kesadaran guru untuk mengerti akan dunia pendidikan yang sesungguhnya, sehingga persoalanpersoalan tersebut dapat meminimalisir dengan baik.

\section{Memahami Kewajiban dan Hak sebagai guru dalam perubahan pendidikan}

Sehubungan dengan ide pemikiran Tilar, yang telah di beritahu penulis sebelumnya pada bagian latar belakang, menegaskan kembali bahwa kunci membangun sumber daya manusia yang unggul dan berkualitas terletak dari perubahan pendidikan. Oleh karena itu perubahan ini

${ }^{16}$ Lukman Hakim, "Pemerataan Akses Pendidikan Bagi Rakyat Sesuai Dengan Amanat Undang-Undang Nomor 20 Tahun 2003 Tentang Sistem Pendidikan Nasional," EduTech: Jurnal Ilmu Pendidikan Dan Ilmu Sosial 2, no. 1 (2016).

${ }^{17}$ Frets Keriapy, "Pendidikan Kristiani Transformatif Berbasis Multikultural Dalam Konteks Indonesia," REGULA FIDEI: Jurnal Pendidikan Agama Kristen 5, no. 2 (2020): 82-93.

18 Tuti Sumiati, "Problematika Pendidikan Di Indonesia Dan Solusi Pemecahannya," Statement| Jurnal Media Informasi Sosial dan Pendidikan 1, no. 1 (2011): 43-48. 
bisa dapat terealisasikan apabila seluruh komponen pendidikan siap untuk mulai membenahi diri dalam mengejar ketertingalan. ${ }^{19}$ Pembenahan diri ini bisa dilakukan apabila guru telah sadar akan apa yang menjadi kewajiban dan haknya dalam dunia pendidikan. Sebab dengan kesadaran ini maka guru akan mengetahui aspek-aspek apa yang dibutuhkan dalam meningkatkan kualitas kependidikannya. Sebab dengan kualitas kependidikan yang baik akan menghasilkan pula kualitas sumber daya manusia yang baik. Sehingga guru dalam proses pembelajaran dapat melaksanakan tugas sesuai dengan aturan yang ada.

Kewajiban dan hak guru bukanlah hal yang baru dalam dunia pendidikan. Hal ini sudah menjadi tuntutan dan mendarah daging dalam keberlangsungan tugasnya sehari-hari di sekolah. Kewajiban adalah segala sesuatu yang harus dilakukan dengan penuh rasa tanggung jawab. Suatu kewajiban dapat dikatakan sebagai hutang yang harus dilunasi untuk memperoleh apa yang harus seseorang miliki. Sedangkan hak adalah sesuatu yang berbicara mengenai hal apa yang diterima seseorang setelah ia melakukan kewajibannya. ${ }^{20}$ menurut UU no 14 tahun 2005 pasal 13-22, tentang hak dan kewajiban guru, telah di atur bahwa guru memiliki kewajiban, diantaranya:

1. Pendidik sebagai tenaga professional bertugas dalam merencanakan dan melaksanakan program pembelajaran, seperti pembuatan : Rpp, silabus dan KKM.

2. Pendidik harus memiliki kualifikasi minimum dan sertifikasi sesuai dengan jenjang kewenangan mengajar, sehat jasmani dan rohani, serta memiliki kemampuan untuk mewujudkan tujuan pendidikan nasional.

3. Menciptakan suasana pendidikan yang bermakna, menyenangkan, kreatif, dinamis, dan dialogis.

4. Mempunyai komitemen secara professional dalam meningkatkan mutu pendidikan; dan

5. Memberi teladan dan menjaga nama baik lembaga, profesi, dan kedudukan sesuai dengan kepercayaan yang diberikan kepadanya. ${ }^{21}$ Inilah point-point yang menjadi tuntutan dan kewajiban yang harus dilakukan oleh guru dalam menjalankan tugasnya demi mencapai perubahan pendidikan.

Selain itu, guru juga memiliki hak yang diperoleh dari pelaksanaan kewajiban tersebut. Adapun hak ini telah diatur dalam UU yang sama berkaitan tentang kewajiban guru yang telah di jelaskan sebelumnya. Untuk itu adapun hak-hak guru, menurut UU no 14 tahun 2005, terdiri dari:

1. Pendidik berhak menerima penghasilan dan jaminan sosial yang pantas dan memadai

2. Pendidik berhak menerima penghargaan sesuai dengan prestasi kinerja dari tugas kewajiban yang telah dilakukan oleh guru

\footnotetext{
19 IBID

${ }^{20}$ Siti Mawaddah, "Kompetensi Profesi Guru Dalam Menjalankan Peran, Hak , Dan Kewajiban Guru," Seri Publikasi Pembelajaran 1, no. 2 (2021): 1-21.

${ }^{21}$ UU NO 14 TAHUN 2005 PASAL 13-22, TENTANG HAK DAN KEWAJIBAN GURU
} 
W. Petrus, D. S. A. Nainggolan, T. Tafonao: Peran Guru Profesional dalam memajukan...

3. Pemberian promosi kenaikan jabatan dan penghargaan bagi pendidik dan tenaga kependidikan dilakukan berdasarkan tinjauan latar belakang pendidikan, pengalaman, kemampuan, dan prestasi kerja dalam bidang pendidikan.

4. Pendidik dan tenaga kependidikan berhak mendapatkan sertifikasi pendidikan apabila sudah memenuhi standar kelayakan yang ditetapkan oleh pemeritah.

5. Adanya perlindungan hukum dalam melaksanakan tugas dan hak dari hasil kekayaan intelektual; dan

6. Kesempatan yang didapatkan dalam mempergunakan sarana, prasarana, dan fasilitas kependidikan guna mendukung kelancaran pelaksanaan tugas yang dilakukan di lingkungan sekolah. ${ }^{22}$

Dengan mengetahui kewajiban dan hak guru sebagaimana yang telah di paparkan dalam tulisan ini diharapkan menjadi acuan untuk guru dalam mengevaluasi dirinya sejauh mana telah memberikan kontribusi dalam perubahan pendidikan. Guru yang menjalankan kewajiban dan haknya dengan benar adalah guru yang sadar akan panggilan jiwa yang diembannya. Tak jarang guru seperti ini akan selalu dikenang murid dalam ingatannya dan diakui sebagai sosok yang bernilai dalam kehidupannya. Bukan bermaksud untuk menghakimi, tetapi faktanya masih banyak guru yang belum sepenuhnya menjalankan kewajibannya dengan benar tetapi menuntut haknya lebih tinggi dari apa yang seharusnya dilakukannya. Berdasarkan penelitian yang dilakukan oleh Mukhtar bahwa rata-rata guru yang melaksanakan di SMP Negeri Masjid Raya belum ada peningkatan kinerja secara signifikan berdasarkan informasi yang disampaikan oleh kepala sekolah di lapangan. ${ }^{23}$

Sehubungan dengan kewajiban dan hak guru, sebagaimana dalam point-point yang telah dipaparkan dalam tulisan ini, menjadi sebuah kesadaran bagi guru untuk melakukan kewajiban dan hak tersebut dengan semestinya. Sebab implementasi kewajiban dan hak guru sangat mempengaruhi kualitas kependidikan. Oleh karena itu, dengan memahami hal ini diharapkan guru terus membenahi dirinya guna mencapai kualitas mutu pendidikan yang diharapakan, yakni dalam mencapai tujuan pendidikan nasional, untuk mencerdaskan kehidupan bangsa dengan cara mengelola Sumber Daya Manusia yang berkualitas dan siap menerima tantangan dunia global secara mandiri dan kreatif.

Penulis melihat bahwa dalam menjalankan kewajiban dan hak ini melibatkan suatu persyaratan yang menjadi aturan sebagai landasan yang harus dipenuhi oleh guru. Dimana persayaratan ini bertujuan untuk memudahkan guru agar siap dalam melaksanakan kewajiban dan hak guru sebagaimana mestinya. Adapun syarat-syarat menjadi guru seorang guru adalah antara lain memiliki pengetahuan memadai, fisik yang sehat secara jasmani dan rohani, psikis baik dan kepribadian yang disiplin dan bertanggung jawab. Sedangkan untuk persyaratan akademisnya telah di atur dalam Undang-Undang No. 14 tahun 2005, yang terdiri dari, guru

22 IBID

${ }^{23}$ Mukhtar, "Strategi Kepala Sekolah Dalam Meningkatkan Kinerja Guru Pada Smp Negeri Di Kecamatan Masjid Raya Kabupaten Aceh Besar," Jurnal Administrasi Pendidikan : Program Pascasarjana Unsyiah 3, no. 3 (2015): 103-117. 
W. Petrus, D. S. A. Nainggolan, T. Tafonao: Peran Guru Profesional dalam memajukan...

wajib memiliki kualifikasi akademik, guru wajib memiliki kompetensi sebagai agent pembelajaran, dan memiliki sertifikat pendidik yang telah mendapat pengakuan dari pemerintah. Standar ini merupakan acuan untuk melihat bagaimana guru tetap mau mengevaluasi dan mengupgrade diri untuk kualitas kependidikan guna kemajuan pendidikan bangsa melalui perwujudan SDM yang berkualitas. ${ }^{24}$ Hal ini memberikan pemahaman bahwa hubungan standar guru akan berpengaruh pada pelaksanaan kewajiban dan hak. Karena hal ini, sama-sama menyangkut tentang perwujudan kualitas mutu kependidikan.

\section{Memahami fungsi peran guru bagi kemajuan bangsa di era industri 4.0}

Sehubungan dengan pemaparan sebelumnya berkaitan dengan harapan masyarakat tentang kemajuan pendidikan di Indonesia, maka yang menjadi aspek dalam mewujudkan hal tersebut adalah mendorong guru untuk tetap memperbaiki kualitas pengajarannya. Hal ini diyakini akan menjadi sebuah keberhasilan apabila guru sadar tentang kualitas yang diwujudkan melalui kinerjanya. Sebab kualitas pendidikan yang bermutu akan terlihat pada setiap sumber daya manusia yang telah menamatkan diri dari setiap lembaga pendidikan. Jika hal ini para guru menyadari betapa penting perbaiki mutu maka guru akan menyadari bahwa masalah pendidikan haruslah diperhatikan dan dikerjakan secara serius. Oleh karena itu perlu adanya evaluasi kinerja terus menerus demi menjaga kualitas sebagai pendidik. Selain hal tersebut, menurut Alifah salah satu poin penting dalam memperbaiki kualitas pendidikan adalah melalui input, proses dan hasil. Ketiga hal ini menjadi kunci utama untuk mencapai keberhasilan dalam pendidikan di Indonesia. $^{25}$

Kajian ini merupakan suatu pembelajaran kepada setiap guru, apa bila setiap guru memahami tugasnya sebagai pendidik yang profesional dalam bidangnya, sehingga hal ini berdampak pada kemajuan peserta didik dengan baik, apa yang dipelajari oleh siswa sekarang ini baik di ruang-ruang kelas maupun di luar kelas dan hal itu akan tercermin di masa mendatang. Artinya bahwa guru yang berperan penting dalam mempengaruhi cara berpikir dan cara pandang siswa dalam mencapi sebuah keberhasilan dalam dunia pendidikan.

Peran guru sangat penting dalam mewujudkan kemajauan bangsa di era industri 4.0. Dengan memperhatikan kewajiban dan hak guru serta hubungan kualifikasi guru dengan mutu kependidikannya serta menyadari bahwa peran guru sebagai profesi menuntut pada suatu keahlian. Hal ini harus menjadi sebuah jawaban dalam memberantas masalah pendidikan di Indonesia. Pembenahan diri dan kesadaran akan komitemen dalam tanggung jawab mencerdasakan kehidupan bangsa merupakan indikator penting yang harus dikerjakan dan dicapai oleh setiap adalah guru.

${ }^{24}$ Sunhaji Sunhaji, "Kualitas Sumber Daya Manusia (Kualifikasi, Kompetensi Dan Sertifikasi Guru)," Jurnal Kependidikan 2, no. 1 (1970): 142-160.

${ }^{25}$ Siti Alifah, "Peningkatan Kualitas Pendidikan Di Indonesia Untuk Mengejar Ketertinggalan Dari Negara Lain (Education In Indonesia And Abroad: Advantages And Lacks)," Cermin: Jurnal Penelitian 5, no. 1 (2021): 113-123. 
W. Petrus, D. S. A. Nainggolan, T. Tafonao: Peran Guru Profesional dalam memajukan...

Berdasarkan penjelasan tersebut maka penulis akan menguraikan beberapa indikator penting yang menjadi suatu acuan bagi dalam menjalankan tugas setiap hari, antara lain:

1. Entrepreneur mindset adalah sebuah konsep pola pikir yang dilatih untuk peserta didik selalu berani mengambil resiko dan pantang menyerah. Hal ini bertujuan memberikan kemampuan bagi peserta didik untuk tidak takut gagal, tetap berani mencoba dan menyadari kesalahan sendiri sebagai evaluasi dirinya. ${ }^{26}$

2. Mengajarkan pemikiran kritis, sehubungan dengan ini guru berperan menumbuhkan rasa ingin tahu dari dalam diri siswa. Cermat dalam menanggapi suatu hal kemudian melakukan penyelidikan dan menganalisis hal tersebut adalah aspek yang harus di asah oleh guru dalam melaksanakan peran ini. Dengan kata lain dengan guru menjalankan peran ini, menjadikan siswa terbiasa berpikir secara sistematis dan ilmiah dan nantinya akan berguna ketika mereka sudah berada pada dunia industrI dan pekerjaan. ${ }^{27}$

3. Menciptakan tantangan, guru dengan perannnya dalam kemajuan bangsa selain memiliki banyak tantangan akan kinerjanya dalam dunia pendidikan juga diharapkan mampu menciptakan tantangan bagi siswa. Tantangan ini bertujuan agar siswa bergairah untuk mengatasi suatu permasalahan. Tentunya pemberian tantangan ini diharapkan mampu memberikan kesempatan kepada siswa untuk mencari dan menemukan konsep-konsep dan prinsip-prinsip baru secara mandiri yang memudahkan siswa untuk mengingatnya. ${ }^{28}$ biasanya hal ini dilakukan dengan melakukan percobaan berupa melakukan eksperimen dalam proses pembelajaran.

4. Resource linkers, sehubungan dengan istilah ini sangatlah berkaitan dengan perkembangan IPTEK. Dimana pencarian segala informasi di semua bidang kehidupan sangat mudah untuk didapatkan. Namun, dalam dunia pendidikan, guru sangat memegang kendali untuk mengarahkan siswa pada situs maupun link pembelajaran yang tidak bersifat hoaks. Pemilahan informasi belajar yang di lakukan oleh guru untuk memberikan pembelajaan yang pantas melalui media teknologi saat ini adalah tujuan dari peran guru dsebagai resource linkers. Sebab resource linkers ini adalah sebuah pembelajaran yang memanfaatkan teknologi dalam memperoleh informasi dalam kegiatan belajar. ${ }^{29}$ oleh sebab itu, peran guru dalam hal ini berfungsi untuk mendampingi dan mengarahkan siswa agar memperoleh informasi yang benar dalam penggunaan teknologi.

5. Membangun karakter, di era globalisasi saat ini dalam sistem pembelajaran abad 21, para guru seyogianya mengokohkan karakter dirinya dalam membangun karakter para siswanya dengan cara menanamkan nilai-nilai postif bagi siswa, karena guru merupakan

26 Aji Rinaldo, Christian m. EdoHogantara, Peta Jalan UKM 4.0: Profesional, Produktif, Kreatif, \& Entrepreneurial (Jakarta: Gramedia Pustaka Utama, 2017).

27 Nuraida, D. (2019). Peran Guru Dalam Mengembangkan Keterampilan Berpikir Kritis Siswa Dalam Proses Pembelajaran. Jurnal Teladan: Jurnal Ilmu Pendidikan Dan Pembelajaran, 4(1), 51-60.

${ }^{28}$ Endang Sri Wahyuningsih, Model Pembelajaran Mastery Learning Upaya Peningkatan Keaktifan Dan Hasil Belajar Siswa (Deepublish, 2020). 2012).

${ }^{29}$ Tapip Asep Yani, Otonomi Pendidikan: MBS \& Pengambil Keputusan Partisifatif (Jakarata: Humaniora, 
W. Petrus, D. S. A. Nainggolan, T. Tafonao: Peran Guru Profesional dalam memajukan...

role model bagi siswa. ${ }^{30}$ Artinya disamping guru memberikan pengajaran kognitif kepada siswa juga memberikan contoh tindakan afektif yang diselasarkan pada tindakan psikomotorik siswa dalam kehidupan sehari-hari. Membangun karakter ini sangat penting, sebab siswa yang pintar jika tidak mempunyai karakter yang baik akan menjadi suatu masalah yang berdampak pada diri sendiri dan merugikan orang lain (masyarakat).

6. Membangun komunitas belajar yang menyenangkan, dalam hal ini guru bertugas sebagai pengelola kelas yang bertujuan untuk memandu dan memotivasi siswa untuk terlibat secara interaktif dan elaboratif dalam menyelesaikan masalah belajar. Pada tahapan ini guru dengan kata lain berperan sebagai otoritatif, sehingga siswa menjadi dirinya sendiri untuk bertanggung jawab menyelesaikan masalah belajar yang dia hadapi secara mandiri atau pun secara team. Kemandirian ini lah yang menjadi aspek yang harus diasah oleh guru guna mendorong pola pikir yang baru dan bersifat luas, dan membimbing siswa untuk terus belajar bagaimana belajar bersama-sama. Menghargai argument anak didik adalah tujuan dari pelaksanaan peran ini. Sebab dalam pelaksanaan peran ini, anak didik akan bebas berpikir, berpendapat dan berupaya mendapatkan solusi sehingga daya kritis mereka meningkat. ${ }^{31}$

Berdasarkan penjelasan ini, maka penulis melihat dan meyakini bahwa setiap problem yang selalu mengganggu aktifitas pembelajaran selama ini akan dapat teratasi dengan, apa bila para guru menerapkan enam indikator di atas. Sebab kemajuan tersebut terjadi karena adanya konsep yang selalu diterapakan kepada siswa dengan diberi ruang dalam mengeksplorasi dirinya dan kemampuanya dengan dikontrol oleh setiap guru demi meningkatkan kualitas sumber daya manusia yang unggul. Oleh karena itu hendaknya para para guru menciptakan suasana pembelajaran yang berpartisipasi secara aktif, inisiatif, kreatif dan inovatif dalam proses pembelajaran, sehingga proses pembelajaran menjadi sebuah kehidupan yang menyenangkan bagi siswa dan bukan menjadi keterpaksaan. Selain hal itu, maka dalam menjalankan enam indicator ini, guru juga harus menggunakan metode yang bervariasi, model pembelajaran yang menginspirasi, dan pendekatan pembelajaran yang menyenangkan serta media yang menunjang proses pembelajaran tersebut. Dengan upaya-upaya seperti ini, maka secara otomatis minat belajar peserta didik semakin meningkat.

\section{Kesimpulan}

Tulisan ini mengkaji peran profesional guru dalam meningkatkan kemajuan pendidikan di era industri 4.0. Kehadiran guru profesional dalam meningkatkan kualitas pendidikan merupakan tugas utama yang harus diperhatikan oleh setiap guru sebagaimana tuntutan dari Undang-Undang Nomor 14 Tahun 2005. Jika selama ini para guru belum memaksimal diri dalam meningkatkan keprofesionalnya dalam melaksanakan tugas, maka sekarang waktunya

${ }^{30}$ Hengkang Bara Saputro, "Peran Guru SD Dalam Membangun Karakter Dan Kecakapan Di Abad 21," in Prosiding Seminar Nasional" Optimalisasi Peran Pendidikan Dalam Membangun Karakter Anak Untuk Menyongsong Generasi Emas Indonesia" (Prodi BK dan PGSD FKIP UAD, 2016), 195-200.

31 Azima Dimayanti, Pengembanagan Profesi Guru (Bandung: Gre Publishing, 2019). 
W. Petrus, D. S. A. Nainggolan, T. Tafonao: Peran Guru Profesional dalam memajukan...

para guru meningkatkan kualitas pengajarannya, karena dengan pengajaran yang berkualitas maka akan melahirkan sumber daya manusia yang berkualitas. Tetapi untuk mencapai target ini maka dibutuhkan suatu kompotensi yang mamadai serta kreativitas dan inovatif yang tinggi dari guru demi mencerdaskan kehidupan anak bangsa, sehingga tujuan dan hasi penelitian ini dapat tercapai sebagaiaman penjelasan dalam artikel ini. Tulisan ini hadir sebagai sumbangsih pemikiran baru dalam melihat aktifitas guru di sekolah. Selain itu, tulisan ini juga menjadi rujukan baru bagi para peneliti berikutnya dalam melanjutkan penelitian ini berkaitan dengan peran profesional guru dalam meningkatkan mutu pendidikan di era industri 4.0.

\section{Referensi}

Abdullah, Syarifuddin. “Zakat Profesi.” Jakarta: PT. Moyo Segoro Agung (2003).

Alifah, Siti. "Peningkatan Kualitas Pendidikan Di Indonesia Untuk Mengejar Ketertinggalan Dari Negara Lain (Education In Indonesia And Abroad: Advantages And Lacks)." Cermin: Jurnal Penelitian 5, no. 1 (2021): 113-123.

Atmanti, Hastarini Dwi. "Investasi Sumber Daya Manusia Melalui Pendidikan." Dinamika Pembangunan 2, no. 1 (2005): 30-39.

Buan, Yohana Afliani Ludo. Guru Dan Pendidikan Karakter: Sinergitas Peran Guru Dalam Menanamkan Nilai-Nilai Pendidikan Karakter Di Era Milenial. Edited by Lorensius Amon. Indramayu: Abad, 2021.

Dimayanti, Azima. Pengembanagan Profesi Guru. Bandung: Gre Publishing, 2019.

Ghony, M. Djunaidi, and Fauzan Almanshur. Metodologi Penelitian Kualitatif. Edited by ArRuzz Media. Yogyakarta, 2012.

Hakim, Lukman. "Pemerataan Akses Pendidikan Bagi Rakyat Sesuai Dengan Amanat UndangUndang Nomor 20 Tahun 2003 Tentang Sistem Pendidikan Nasional.” EduTech: Jurnal Ilmu Pendidikan Dan Ilmu Sosial 2, no. 1 (2016).

Hasyim, M. Hasyim M. "Penerapan Fungsi Guru Dalam Proses Pembelajaran." AULADUNA: Jurnal Pendidikan Dasar Islam 1, no. 2 (2014): 265-276.

Kau, Murhima A. "Peran Guru Dalam Mengembangkan Kreativitas Anak Sekolah Dasar." In Proceeding Seminar Dan Lokakarya Nasional Bimbingan Dan Konseling 2017, 1:157166, 2017.

Keriapy, Frets. "Pendidikan Kristiani Transformatif Berbasis Multikultural Dalam Konteks Indonesia." REGULA FIDEI: Jurnal Pendidikan Agama Kristen 5, no. 2 (2020): 82-93.

Mawaddah, Siti. "Kompetensi Profesi Guru Dalam Menjalankan Peran, Hak, Dan Kewajiban Guru." Seri Publikasi Pembelajaran 1, no. 2 (2021): 1-21.

Mukhtar. "Strategi Kepala Sekolah Dalam Meningkatkan Kinerja Guru Pada Smp Negeri Di Kecamatan Masjid Raya Kabupaten Aceh Besar." Jurnal Administrasi Pendidikan: Program Pascasarjana Unsyiah 3, no. 3 (2015): 103-117.

Mulyani, Fitri. "Konsep Kompetensi Guru Dalam Undang-Undang Nomor 14 Tahun 2005 Tentang Guru Dan Dosen (Kajian Ilmu Pendidikan Islam).” Jurna Pendidikan Universitas Garut 3, no. 1 (2015): 1-8. 
W. Petrus, D. S. A. Nainggolan, T. Tafonao: Peran Guru Profesional dalam memajukan...

Putri, Ayu Dwi Kesuma, and Nani Imaniyati. "Pengembangan Profesi Guru Dalam Meningkatkan Kinerja Guru (Professional Development of Teachers in Improving the Performance of Teacher)." Jurnal Pendidikan Manajemen Perkantoran 2, no. 2 (2017): 202-211.

Qomario, Qomario, Siti Kurniasih, and Hetty Anggraini. "Studi Analisis Latar Belakang Pendidikan, Sertifikasi Guru Dan Usia Guru Paud Di Kota Bandar Lampung Berdasarkan Hasil Nilai Uji Kompetensi Guru (UKG).” Jurnal Caksana: Pendidikan Anak Usia Dini 1, no. 02 (2018).

Rinaldo, Christian m. EdoHogantara, Aji. Peta Jalan UKM 4.0: Profesional, Produktif, Kreatif, \& Entrepreneurial. Jakarta: Gramedia Pustaka Utama, 2017.

Sahaka, Amir. "Profesi, Profesional Dan Pekerjaan." Jurnal Teknologi Pendidikan Madrasah 2, no. 1 (2019): 61-69.

Saputro, Hengkang Bara. "Peran Guru SD Dalam Membangun Karakter Dan Kecakapan Di Abad 21." In Prosiding Seminar Nasional" Optimalisasi Peran Pendidikan Dalam Membangun Karakter Anak Untuk Menyongsong Generasi Emas Indonesia", 195-200. Prodi BK dan PGSD FKIP UAD, 2016.

Sujana, I Wayan Cong. "Fungsi Dan Tujuan Pendidikan Indonesia." Adi Widya: Jurnal Pendidikan Dasar 4, no. 1 (2019): 29-39.

Sumiati, Tuti. "Problematika Pendidikan Di Indonesia Dan Solusi Pemecahannya." Statement| Jurnal Media Informasi Sosial dan Pendidikan 1, no. 1 (2011): 43-48.

Sunhaji, Sunhaji. "Kualitas Sumber Daya Manusia (Kualifikasi, Kompetensi Dan Sertifikasi Guru)." Jurnal Kependidikan 2, no. 1 (1970): 142-160.

Tafona'o, Talizaro. "Kepribadian Guru Kristen Dalam Perspektif 1 Timotius 4:11-16." Evangelikal: Jurnal Teologi Injili dan Pembinaan Warga Jemaat 3, no. 1 (2019): 62-81.

Utomo, Susilo Setyo. "Guru Di Era Revolusi Industri 4.0.” Format Pendidikan Untuk Meningkatkan Daya Saing Bangsa 1, no. 1 (2019): 70-83.

Wahyuningsih, Endang Sri. Model Pembelajaran Mastery Learning Upaya Peningkatan Keaktifan Dan Hasil Belajar Siswa. Deepublish, 2020.

Warsono, Warsono. "Guru: Antara Pendidik, Profesi, Dan Aktor Sosial.” The Journal of Society \& Media 1, no. 1 (2017): 1-10.

Wibawa, Fajri Arif, and Meyta Pritandhari. "Pemanfaatan Teknologi Informasi Dalam Pembelajaran Era Revolusi Industri 4.0." In Seminar Nasional Penelitian Dan Pengabdian Kepada Masyaraka, 3:109-117. Lampung: Universitas Muhammadiyah Metro, 2020.

Yani, Tapip Asep. Otonomi Pendidikan: MBS \& Pengambil Keputusan Partisifatif. Jakarata: Humaniora, 2012. 